\title{
A NOVEL BIO-COAGULANT AID TO TREAT HIGH TURBID WATER CONTAINING HUMIC ACIDS
}

\author{
Hossam Altaher ${ }^{1,2}$, Tarek E. Khalil ${ }^{3}$, Reda Abubeah ${ }^{4}$ \\ ${ }^{1}$ Department of Chemical Engineering Technology, Yanbu Industrial College, Saudi Arabia \\ ${ }^{2}$ Present address: University of Nizwa, Department of Chemical and Petrochemical Engineering, Sultanet of Oman, \\ ${ }^{3}$ Department of Chemistry, Faculty of Science, Alexandria University, Egypt \\ ${ }^{4}$ Department of Chemical Engineering, Faculty of Engineering, El-Minia University, Egypt \\ Email: haltaher@hotmail.com
}

\begin{abstract}
In general, the production of potable water from raw water sources involves the coagulation or flocculation process to remove turbidity. Alum has been widely used as a coagulant; however, there is a concern about its associated risk of Alzheimer's disease. As a result, there has been considerable interest in the development of natural coagulants and coagulant aids in order to reduce the dose of alum. This study aimed at evaluating the use of Corchorus Olitorius L. (COL), a leafy vegetable grown in Africa and the Middle East, as a novel coagulant aid over other synthetic coagulant aids. It is a widely produced agricultural waste and does not require further chemical treatment. Various tests were carried out to evaluate the optimal dosage and conditions required to achieve the optimum removal of both turbidity and humic acid from water. Based on the results of the jar test, COL was found to be an efficient coagulation aid. It has the ability to reduce the primary coagulant dose (from $600 \mathrm{mg} / \mathrm{L}$ to $300 \mathrm{mg} / \mathrm{L}$ ) and residual turbidity (from 5.63 to $2.3 \mathrm{NTU}$ ). This novel coagulant aid reduced the concentration of total organic carbon to the zero level and increased the rate of flocculation.
\end{abstract}

Keywords: Alum, Corchorus Olitorius L., Coagulation, Flocculation, Turbidity, Water Treatment.

\section{INTRODUCTION}

The water from surface or ground sources is not clean enough for consumption as it contains particles of the colloidal suspension. These particles cannot be separated using conventional physical methods, such as filtration or settling, unless they are agglomerated through processes like coagulation and flocculation. The colloids commonly found in the wastewater are stable because of their electrical charge (positive or negative). However, most colloidal particles in the wastewater possess a negative charge (Farajnezhad and Gharbani, 2012). The coagulation process is effective in removing high concentrations of organic pollutants, heavy metals, and certain anions. It is also effective in reducing the color of particles, chemical oxygen demand (COD), and total suspended solids (TSS). Aluminum salts are the most widely used coagulants; however, they may cause numerous neurological disorders in humans (Tassinari et al., 2013). It has been reported that iron salts can be more efficient and cheaper than the alluminum salts, but their high importation cost is seen as a serious setback for the developing countries 
(Ugonabo et al., 2012). One of the major disadvantages related to the use of coagulants is the huge amount of toxic sludge produced during the process (Zemmouri et al., 2012).

There are two main types of coagulants, namely primary coagulants and coagulant aids, used in the water treatment process. The role of primary coagulants is to neutralize the electrical charges of the colloidal particles in the water, which causes the particles to clump together. Comparatively, the addition of coagulant aids increases the floc's density, adds roughness to the flocs so that they do not break up during the mixing and settling process, and reduces the flocculation and settling time (Aziz et al., 2007).

Lime and bentonite, clay minerals, activated $\mathrm{Si}_{2}$, and cationic or anionic polyelectrolytes are some examples of coagulant aids (Cheng et al., 2008). Previous studies have investigated the use of tannin as a primary coagulant and coagulant aid in water treatment (Özacar and Şengil, 2002). Chitosan has also been investigated as a coagulant or flocculent for a wide variety of suspensions (Zemmouri et al., 2012; Hu et al., 2013). A new coagulant aid, Enteromorpha extract, was also investigated for enhancement of the coagulation performance (Zhao et al., 2013).

The most important benefit of using a coagulant aid is the reduction in the amount of a coagulant used in any given case, which in turn reduces the sludge and chemical residuals present in the drinking water. In an attempt to avoid the hazards of using metal salts as coagulants, more interest has been generated towards the development of natural coagulants and coagulant aids (Amud and Amoo, 2007; Ugonabo et al., 2012; Hu et al., 2013; Yang et al., 2013, Choy et al., 2014). However, most of the natural coagulants and coagulant aids are very expensive. Hence, it has become necessary to develop non-toxic, efficient, and low-cost coagulant aids (Zhao et al., 2013). The natural coagulants may consist of plant seeds, leaves, roots, and animal extracts (Gunaratna et al., 2007, Fedala et al., 2015). Other natural substances tried as coagulant aids include Moringa olifera (drumstick tree), red bean, and red maize (Gunaratna et al., 2007; Poumaye et al., 2012). The performance of agro-based materials, such as Surjana seeds, Nirmali seeds, and maize, as coagulant aids with alum as a coagulant was investigated by Raghuwanshi et al. (2002).

For any new coagulant/coagulant aid to be considered, it must be efficient, cost-effective, sustainable, and environmentally safe.

Corchorus olitorius L. (COL) is a leafy vegetable grown in Africa and the Middle East. It is native to Egypt and popular in the Mediterranean regions, Japan and Southeastern Asia. The young green leaves and shoots of this vegetable can be picked and cooked. The stems and roots are considered as agricultural wastes. COL possesses a wide spectrum of medicinal applications. Its leaves and roots are used as herbal medicines. Traditionally, its leaves have been used for the treatment of pain, fever, chronic cystitis, and tumors. Its seeds have been reported to possess estrogenic activity (Oyedeji and Bolarinwa, 2013), and it also induces wound healing and regenerates injured tissues (Barku et al., 2013). Apart from these advantages, a thorough literature survey indicates that COL has not been used as a coagulant or coagulant aid.

The aim of this study is to investigate the use of COL waste as a coagulant aid to enhance the turbidity and total organic carbon (TOC) removal and accelerate the flocculation time. Operating variables that were investigated included turbidity, $\mathrm{pH}$, coagulant and 
coagulant aid dosages, slow mixing time, and sedimentation time. A comparison was also drawn between the treatment methods, with or without filtration. The COL coagulant aid was optimized on the basis of TOC removal, residual turbidity, and flocculation time.

\section{MATERIALS AND METHODS}

\subsection{MATERIals}

The kaolin stock solution (turbid water) was prepared by dissolving $10 \mathrm{~g}$ of kaolin (Acros Organics, Gee, Belgium) in 1 liter of distilled water. The solution was stirred for 24 hours for complete hydration of kaolin particles. The turbid water was prepared by adding part of the stock solution to distilled water to reach the required turbidity. The alum solution (Panreac Quimica SA, Spain) was prepared by dissolving $10 \mathrm{~g}$ of the solid salt in 1 liter of distilled water. This solution was used as a coagulant without any further dilution. The coagulant aid was freshly obtained from the local market of Saudi Arabia. The stems were cut into small pieces and crushed with the help of a mortar and pestle. The liquid extract was collected and kept in a glass container. The working solution was prepared by dissolving $1 \mathrm{~g}$ of this extract in 1 liter of distilled water. The humic acid solution was prepared by dissolving $1 \mathrm{~g}$ of the solid material (LobaChemiw, India) in 1 liter of distilled water. A suitable volume of humic acid solution was added to reach the required humic acid concentration in the turbid water (as illustrated in Figure 6).

\subsection{COAGULATION EXPERIMENTS}

The coagulation or flocculation tests were conducted using a conventional jar test apparatus equipped with six beakers of 1000 $\mathrm{mL}$ volume. The turbid water samples (100 NTU) were stirred for $1 \mathrm{~min}$ to assure the homogeneity of the turbid water. The beakers were filled with $500 \mathrm{~mL}$ of turbid water for each test run. No adjustment of $\mathrm{pH}$ was performed unless when evaluating the effect of $\mathrm{pH}$ on the coagulation process. Calculated amounts of coagulant were added to each beaker to reach the required dose. Care was taken not to change the total volume of the turbid water. Rapid mixing was performed at $250 \mathrm{rpm}$ for $1 \mathrm{~min}$ followed by slow mixing at $50 \mathrm{rpm}$ for $20 \mathrm{~min}$. The flocs formed were then allowed to settle for $40 \mathrm{~min}$. After the settling period, the samples were withdrawn from the supernatant for further analysis. All the experiments were carried out at an ambient temperature of $20-22{ }^{\circ} \mathrm{C}$. The different factors affecting the coagulation process were studied by changing one factor at a time while keeping the other factors constant. For instance, to study the effect of initial $\mathrm{pH}$, all other factors were kept constant, and the $\mathrm{pH}$ of the turbid water was adjusted to different values by using either $1 \mathrm{~N} \mathrm{H}_{2} \mathrm{SO}_{4}$ or $1 \mathrm{~N}$ $\mathrm{NaOH}$. The experimental conditions are summarized in Table 1.

TABLE 1: EXPERIMENTAL CONDITIONS OF THE COAGULATION/FLOCCULATION EXPERIMENTS

\begin{tabular}{|c|c|c|c|c|c|}
\hline & $\begin{array}{c}\text { Rapid mixing } \\
\text { time,min / } \\
\text { rate,rpm }\end{array}$ & $\begin{array}{c}\text { Slow mixing } \\
\text { time,min / } \\
\text { rate,rpm }\end{array}$ & $\begin{array}{l}\mathrm{pH} \text { of turbid } \\
\text { water }\end{array}$ & $\begin{array}{l}\text { Dose of alum as mg/L } \\
\qquad \mathrm{Al}_{2} \mathrm{O}_{3} \cdot 18 \mathrm{H}_{2} \mathrm{O}\end{array}$ & Dose of COL, mg/L \\
\hline Effect of alum as the primary coagulant dose & $1 / 250$ & $20 / 50$ & 7.5 & $20-1800$ & - \\
\hline Effect of $\mathrm{COL}$ as the primary coagulant dose & $1 / 250$ & $20 / 50$ & 7.5 & - & $2-200$ \\
\hline Effect of $\mathrm{pH}$ when using alum & $1 / 250$ & $20 / 50$ & $1-11$ & 600 & - \\
\hline Effect of $\mathrm{pH}$ when using alum+COL & $1 / 250$ & $20 / 50$ & 7.5 & 300 & 3 \\
\hline Effect of COL as coagulant aid on removal of turbidity & $1 / 250$ & $20 / 50$ & 7.5 & $20-600$ & $2-200$ \\
\hline $\begin{array}{l}\text { Optimization of alum dose and coagulant doses for } \\
\text { removal of humic acids }\end{array}$ & $1 / 250$ & $20 / 50$ & 7.5 & $20-600$ & $2-10$ \\
\hline Effect of coagulant aid on the flocculation time & $1 / 250$ & $20 / 50$ & 7.5 & 300 & 3 \\
\hline
\end{tabular}




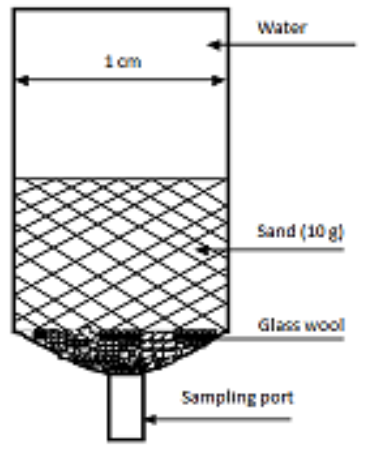

Fig.1. Schematic diagram of the filtration column

The filtration was performed in a column of $60 \mathrm{~cm}$ height and $1 \mathrm{~cm}$ diameter. Then $10 \mathrm{~g}$ of sand was placed in the column and was supported by glass wool. The sand was introduced to the bed without stratification. After the introduction of sand, gentle tapping was applied on the outer surface of the column to avoid possible channeling through the sand bed. A schematic diagram of the filtration column is depicted in Figure 1. The supernatant from the coagulation or flocculation process was introduced into the column by using a peristaltic pump. The effluent from the column was collected, and the residual turbidity was measured. Duplicates of the experiments were conducted, and the average was taken.

\subsection{ANALYTICAL METHOD}

The TOC representing the humic acid and residual coagulant aid was determined by following the Hach Method 10129 of the Hach Water Analysis Handbook (Hack 1997), using DRB200 Reactor and DPR 890 colorimeter. Turbidity was measured using the calibrated Nephelometer (Hack Turbidity Meter Model 2100), and $\mathrm{pH}$ was measured using $\mathrm{pH}$ 501, EuTech Instruments.

\section{RESULTS AND DISCUSSION}

3.1. Characteristics OF SAND Bed, TURbID WATER, AND COL

The characteristics of the sand bed used were $\mathrm{d} 10$ (the grain diameter at $10 \%$ passing), $\mathrm{d} 60$
TABLE 2A: CHARACTERISTICS OF TURBID WATER

\begin{tabular}{|c|c|c|c|c|c|c|}
\hline \multicolumn{2}{|c|}{ TOC, $\mathrm{mg} / \mathrm{L}$} & $\mathrm{pH}$ & \multicolumn{2}{|c|}{ Turbidity, NTU } & $\mathrm{EC}, \mathrm{S} / \mathrm{m}$ & $\mathrm{TDS}, \mathrm{mg} / \mathrm{L}$ \\
\hline \multicolumn{2}{|c|}{50} & 7.5 & \multicolumn{2}{|c|}{100} & 0.204 & 102 \\
\hline \multicolumn{7}{|c|}{$\begin{array}{l}\text { EC: Electrical conductivity; TOC: Total carbon content; TDS: Total dissolved } \\
\text { solids }\end{array}$} \\
\hline \multirow{2}{*}{\multicolumn{7}{|c|}{$\begin{array}{l}\text { TABLE 2B: CHARACTERISTICS OF CORCHORUS } \\
\text { OLITORIUS L. (NDOVU AND AFOLAYAN, 2008) }\end{array}$}} \\
\hline & & & & & & \\
\hline & \multicolumn{2}{|c|}{$\begin{array}{c}\text { Total } \\
\text { carbohydrate, } \\
\mathrm{mg} / \mathrm{g}\end{array}$} & $\begin{array}{c}\text { Crude } \\
\text { protein, } \\
\mathrm{mg} / \mathrm{g}\end{array}$ & $\begin{array}{l}\text { Crude } \\
\text { fiber, } \\
\mathrm{mg} / \mathrm{g}\end{array}$ & $\begin{array}{l}\text { Crude } \\
\text { lipid, } \\
\mathrm{mg} / \mathrm{g}\end{array}$ & $\begin{array}{l}\text { Ash, } \\
\mathrm{mg} / \mathrm{g}\end{array}$ \\
\hline Leaves & \multicolumn{2}{|c|}{$695.0 \pm 32.4$} & $162 \pm 3.4$ & $20.3 \pm 1$. & $17.2 \pm 2.9$ & $105.2 \pm 1.0$ \\
\hline Stems & \multicolumn{2}{|c|}{$802.0 \pm 18.2$} & $51.0 \pm 1.8$ & $88.2 \pm 4.8$ & $69.0 \pm 1.3$ & $51.9 \pm 1.2$ \\
\hline
\end{tabular}

(the grain diameter at $60 \%$ passing), and uniformity coefficients (UC) (d60/d10) of the sand bed were $0.173 \mathrm{~mm}, 0.433 \mathrm{~mm}$, respectively, giving a ratio of 2.5 . The turbid water characteristics are illustrated in Table $2 \mathrm{a}$ while the characteristics of COL are introduced in Table $2 \mathrm{~b}$.

\subsection{CoAgulation PERFORManCES OF SEPARATE COAGULANT AND COAGULANT AID}

The effect of alum dosages on the turbidity removal efficiency is shown in Figure 2A. It is apparent from the results that with an increase in the alum dose from 20 to $300 \mathrm{mg} / \mathrm{L}$, the turbidity removal efficiency decreased from $93.5 \%$ to $88.3 \%$, respectively. Further increase in the alum dose to $600 \mathrm{mg} / \mathrm{L}$ caused an increase in the turbidity removal to $94.4 \%$. After this dose, the turbidity removal showed a declining trend. Thus, the highest turbidity removal efficiency $(94.4 \%)$ equivalent to the final turbidity of 5.6 NTU was obtained at an alum dose of $600 \mathrm{mg} / \mathrm{L}$, which was considered as the optimum dose of alum under these conditions. The initial increase in turbidity of the water samples after adding the coagulant may be attributed to the coagulant itself, which added turbidity to the water before starting its coagulating action. At high coagulant doses, aluminum hydroxide is produced, and suspended solids causing turbidity are removed by entrapment into or sorption onto the hydroxide flocs (Demirci et al., 1998). 

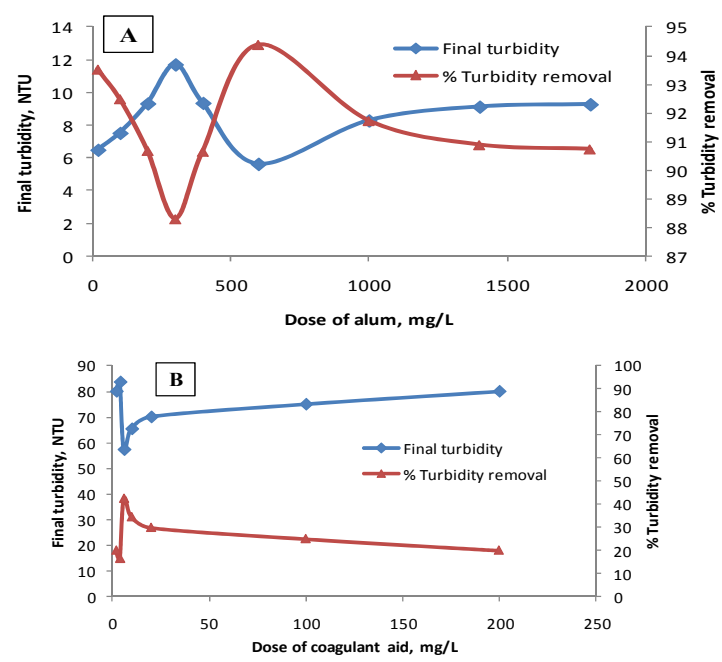

Fig.2. Effect of coagulant or coagulant aid doses on removal of turbidity; A: alum, B: COL

COL was tried as the primary coagulant in a separate experiment. As illustrated in Figure $2 \mathrm{~B}$, the different doses of COL resulted in poor turbidity removal efficiency compared to the alum. The highest efficiency that could be attained was $42.5 \%$. The lowest final turbidity was $57.5 \mathrm{NTU}$ at a dose of $6 \mathrm{mg} / \mathrm{L}$ of COL. An explanation is a steric hindrance that may take place between the polymer molecules at high concentration ( $\mathrm{Hu}$ et al., 2013). The poor performance of natural polymers when used as primary coagulants has been reported by other researchers (Hu et al., 2013; Zhao et al., 2013).

The data presented in Table $2 b$ indicates the presence of high concentrations of both carbohydrates and lipids in the stems. The presence of these constituents increases the content of organic matter in the treated water that represents a disadvantage due to the increase in turbidity in certain situations if the dose of the primary coagulant is not well adjusted.

\subsection{EFFECT OF TURBID WATER PH ON TURBIDITY REMOVAL}

In the coagulation-flocculation process, $\mathrm{pH}$ is a very important factor since the coagulation occurs within a specific $\mathrm{pH}$ range for a particular coagulant. When alum is added to water, a series of soluble hydrolysis species are formed. The species that may be produced includes $\mathrm{Al}(\mathrm{OH}) 3, \quad \mathrm{Al} 3+, \quad \mathrm{Al}(\mathrm{OH}) 2+$, $\mathrm{Al}(\mathrm{OH}) 2+$, and $\mathrm{Al}(\mathrm{OH}) 4-$ ions. These hydrolytic species have positive or negative charges depending on the $\mathrm{pH}$ of the water. The positively charged hydrolytic species can adsorb onto the surface of colloidal particles and destabilize them. The equilibrium state between the concentrations of the above ions depends on the $\mathrm{pH}$ of the solution (Libecki and Dziejowski, 2008). The following equilibrium is obtained shifting to the right with increasing $\mathrm{pH}$ :

$$
\begin{aligned}
\mathrm{Al}^{3+} \rightarrow \mathrm{Al}(\mathrm{OH})^{2+} & \rightarrow \mathrm{Al}(\mathrm{OH})_{2}^{+} \rightarrow \mathrm{Al}(\mathrm{OH})_{3} \\
& \rightarrow \mathrm{Al}(\mathrm{OH})_{4}^{-}
\end{aligned}
$$

The coagulation process with alum as the sole coagulant is capable of achieving significant turbidity removal that is highly $\mathrm{pH}$ dependent (Yan et al., 2008; Yang et al., 2010). As shown in Figure 3A, the removal efficiency with alum decreased with the increase in the $\mathrm{pH}$ from 1 to 3 and then increased with increasing $\mathrm{pH}$ reaching a considerably high level of 7.1. Further increase in the $\mathrm{pH}$ led to slightly decreased removal efficiency. At $\mathrm{pH} 11$, the coagulation efficiency almost reached the slightly high removal value of $97.1 \%$ (final turbidity of 2.9 $\mathrm{NTU}$ ). At this high $\mathrm{pH}$, high precipitation of aluminum will take place leading to the removal of turbidity by the sweep-floc mechanism (Hayrapetyan et al., 2006; Libecki and Dziejowski, 2008). In our tested samples, the higher efficiency of turbidity removal at $\mathrm{pH} 1$ may be attributed to the removal of humic acids, followed by kaolin turbidity. The high turbidity removal at higher $\mathrm{pH}$ may be attributed to the association of humic acids with other suspended solids during the flocculation. 

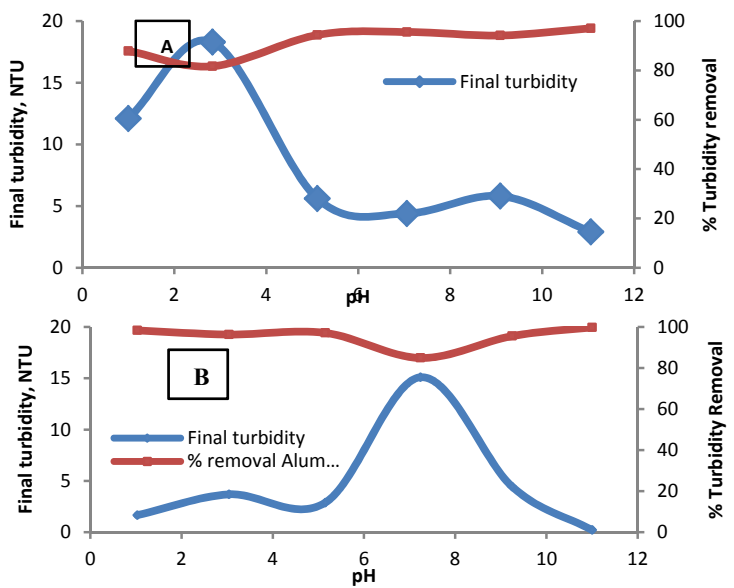

Fig.3. Effect of water $\mathrm{pH}$ on removal of turbidity; A: alum, B: Alum + aid. Alum dose is $300 \mathrm{mg} / \mathrm{L}$ and COL DOS IS $3 \mathrm{mg} / \mathrm{L}$

On the other hand, when COL was added as a coagulant aid, as illustrated in Figure 3B, a slightly different behavior was observed. Increasing the $\mathrm{pH}$ led to a clear decrease in the removal efficiency. The removal efficiency decreased from a value of $98 \%$ at $\mathrm{pH} 1$ to $85 \%$ at $\mathrm{pH}$ 7.5. It was clear that the removal efficiency of using COL as a coagulant aid has been enhanced by the effect of $\mathrm{pH}$. A final turbidity of $0.214 \mathrm{NTU}$ was attained at $\mathrm{pH}$ 11. This value is very low as compared to that obtained when using alum alone, and it is better than the value recommended by World Health Organization (WHO) (1 NTU).

\subsection{EFFECT OF COAGULANT AID ON TURBIDITY REMOVAL}

Two separate experiments were performed. In the first experiment, one set of beakers containing turbid water was treated with alum alone. Another set was treated by adding the same dose of alum and different doses of COL. In the second experiment, the dose of alum was kept constant at its optimum value, with varied doses of COL from one beaker to another. For the second set, the dose of alum was varied, and the dose of COL was kept constant at its optimum value. As illustrated in Figure 4, the addition of the coagulant aid was very influential in decreasing the turbidity. The results indicated that a small dosage of the coagulant aid $(3 \mathrm{mg} / \mathrm{L})$ decreased the water turbidity from 5.63 to $2.3 \mathrm{NTU}$. The later value of turbidity would not have been achieved without using the coagulant aid, even under optimum conditions.

Figure 5 represents the optimization conditions for both the alum and COL. It is clear that the optimum doses of both alum and COL were $300 \mathrm{mg} / \mathrm{L}$ and $3 \mathrm{mg} / \mathrm{L}$, respectively. The correct selection of the optimum combination doses of coagulant and coagulant aid resulted in 50\% decrease in the initial primary coagulant dose. Moreover, the final turbidity has been enhanced to reach a value of $2.3 \mathrm{NTU}$ compared to a value of 5.63 NTU when alum was used alone. As illustrated in Table $2 b$, the stem of the plant contains a substantial amount of proteins. These proteins may impart the positive charge to the solution that will lead to their binding with negatively charged particulates, causing turbidity (Tassinari et al., 2013).

\subsection{HUMIC ACID REMOVAL}

The removal of natural organic matter (NOM) from water can take place through several mechanisms (Lanciné et al., 2008). These mechanisms include charge neutralization,

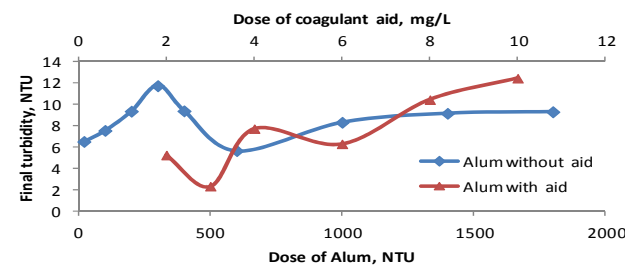

Fig.4.Effect of coagulant dose on removal of turbidity

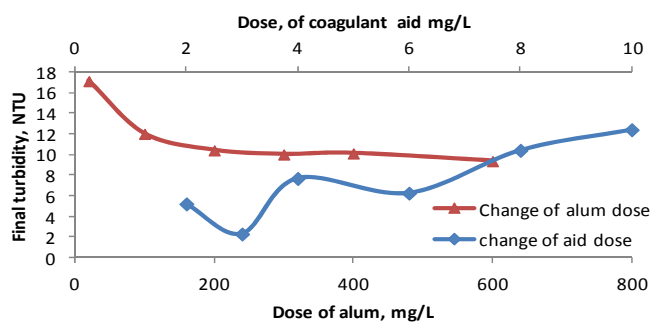

Fig.5. Optimization of alum and coagulant doses 
entrapment, and adsorption. The clay minerals dispersed in natural water have the capacity to adsorb humic substances. Alum dissociates in water to produce cations. The ion exchange between the organic and clay particles due to the presence of these cations is important in this mechanism (Duan and Gregory, 2003). Hydrogen bonding and Van der Waals forces may also play a significant role, particularly if the humic molecules have large uncharged portions and sufficient flexibility to come into contact with the surface of clay particles (American Water Works Association, AWWA, 1979).

To investigate the effect of the coagulant aid for the removal of humic acid, two experiments were performed. In the first one, the dose of alum was kept constant and the dose of COL was changed, and in the second one, the dose of COL was kept constant with varied doses of alum. It is clear from Figures $6 \mathrm{~A}$ and $6 \mathrm{~B}$ that the removal of humic acid is closely related to the removal of turbidity. This may be due to the adsorption of humic substances on the surface of kaolin and its collective flocculation. It can be noticed that the TOC value representing humic acid and residual COL after flocculation reached a zero value at doses greater than $400 \mathrm{mg} / \mathrm{L}$ of the coagulant and for doses of 3 and $5 \mathrm{mg} / \mathrm{L}$ of the coagulant aid. These doses are considered as the optimum doses. The increase in TOC as shown in Figure 6A, after reaching the zero TOC value, is attributed to the residual coagulant aid.

\subsection{EFFECT OF COAGULANT AID ON FLOCCULATION AND SETTLING TIMES}

Two sets of beakers containing the turbid water were used. To the first set, the optimum doses of alum were added to each beaker, and to the second set, optimum doses of both alum and coagulant aid were added.
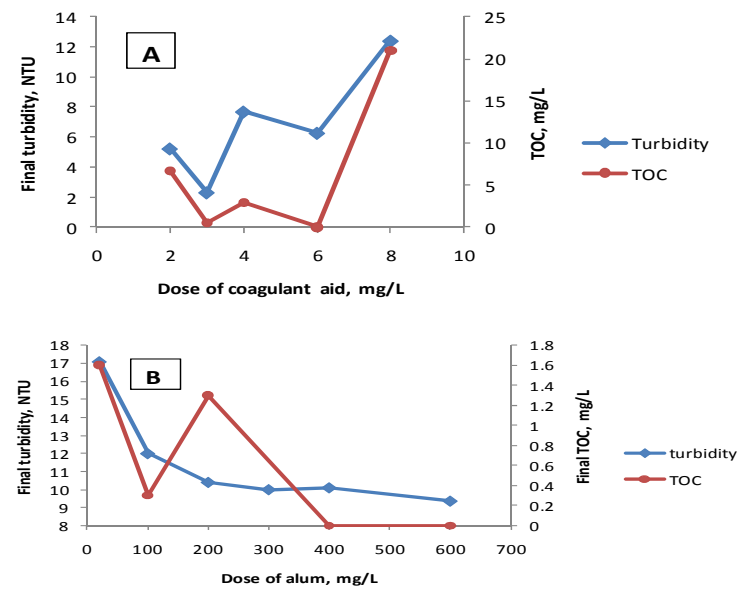

Fig.6. Optimization of alum and coagulant doses for total organic carbon (TOC) removal

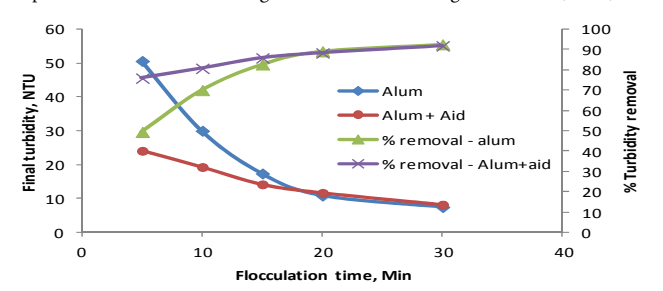

Fig.7. Effect of coagulant aid on the flocculation time

As illustrated in Figure 7, a clear difference can be observed at the initial mixing stages. The solutions containing the coagulant aid were destabilized very rapidly. Within $5 \mathrm{~min}$ of slow mixing followed by sedimentation, the turbidity of water treated with the coagulant aid decreased to $75 \%$ of its initial value compared to $50 \%$ in case of water treated with alum alone.

An important difference between the two systems was the size of the formed flocs. As illustrated in Figure 8, in the case of water treated with coagulant aid, large flocs were observed within $5 \mathrm{~min}$, though they had irregular shapes.

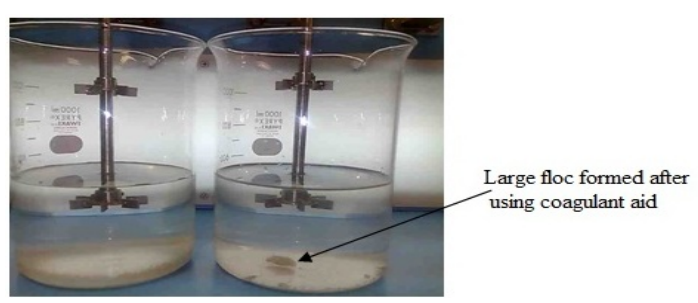

Fig. 8. Effect of coagulant aid on the flocs shape and size; Left: water treated with alum alone, Right: water treated with alum + coagulant aid 
The effect of coagulant aid on sedimentation time was analyzed at different time intervals using optimum doses of alum alone and alum combined with the coagulation aid. The test was performed similarly to the previous one with a slight difference; the slow mixing was continued for 20 min followed by sampling treated water at different time intervals during the settling process. Figure 9 illustrates the settling rate for both the tested systems. Alum showed a much faster sedimentation rate when used alone. A sedimentation time of 40 min was found to remove $92 \%$ of flocs while alum with coagulant aid took $70 \mathrm{~min}$ to achieve this value. These observations may be attributed to the shape of the flocs. The flocs formed when using alum alone were found to be homogeneous and spherical in shape that leads to rapid sedimentation rate, while flocs formed when using alum and coagulant aid were irregular in shape, which resulted in the slow rate of stirring. The flocs formed by using the coagulant aid had probably lower density and gelatinous nature compared to the flocs formed by alum that may lead to reduced settling rate. However, the water produced from the filter bed after sedimentation showed better quality for systems that used the coagulant aid. The residual turbidity in such systems was 0.26 NTU compared to 0.632 NTU when using the alum alone. This can be attributed to the same reason, and the irregular flocs were captured by the filter media much better than the spherical ones. Usually, the physical characteristics of the flocs are important in determining their removal efficiency. For example, large compact flocs have a high settling rate (Wilen et al., 2003), while large and porous flocs aid filtration due to their low permeability (Bushell et al., 2002).

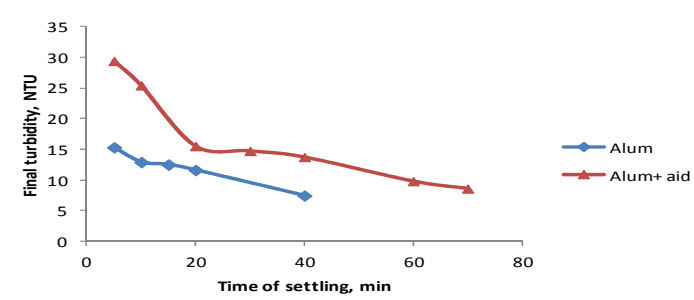

Fig.9. Effect of coagulant aid on the settling time

\section{CONCLUSION}

The conducted experiments confirmed the significant use of this novel coagulant aid, namely COL. The results showed that COL has the ability to reduce the dose of the primary coagulant (alum) and the residual turbidity to almost the half. The coagulant dose was reduced from $600 \mathrm{mg} / \mathrm{L}$ to 300 $\mathrm{mg} / \mathrm{L}$ while the residual turbidity was reduced from 5.63 to $2.3 \mathrm{NTU}$ when using the coagulant aid. COL was found to increase the initial rate of flocculation process, but it did not enhance the settling rate of the formed flocs. However, the water produced after filtration had much better quality compared to that produced without the use of coagulant aid (0.26 NTU and 0.632 NTU, respectively). The comparison between all these results indicated that $\mathrm{COL}$ can be used as a coagulant aid.

\section{REFERENCES}

[1] AWWA, Committee Report, Organic removal by coagulation: a review and research, 1979.

[2] Aziz H.A., Alias S., Assari F., Adlan M.N., The use of alum, ferric chloride and ferrous sulfate as coagulants in removing suspended solids, colour and COD from semi-aerobic landfill leachate at controlled $\mathrm{pH}$, Waste Management Research, 25 (6), 556-565, 2007.

[3] Barku V.Y.A., Boye A. and Quansah N., Antioxidant and wound healing studies on the extracts of CorchorusOlitorius leaf. World Essays Journal, 1 (3) 67-73, 2013.

[4] Bushell G.C, Yan Y.D., Woodfield D., Raper J., Amal R., On techniques for the measurement of the mass fractal dimension of aggregates, 
Advanced Colloidal Interface Science, 95 (1) 1-50, 2002.

[5] Cheng W.P., Chi F.H., Li C.R., Yu F., A study on the removal of organic substances from lowturbidity and low-alkalinity water with metalpolysilicate coagulants. Colloids and Surfaces A Physicochemical Engineering Aspects, 312, 238244, 2008.

[6] Choy S.Y., Prasad K.M.N., Wu T.Y., Raghunandan M.E., Ramanan R.N., Utilization of plant-based natural coagulants as future alternatives Utilization of plant-based natural coagulants as future alternatives towards sustainable water clarification. Journal of Environmental Sciences, 26 (11), 2178-2189, 2014.

[7] Demirci S., Erdogan B., Ozcimder R., Wastewater treatment at the petroleum refinery, kirikkale, Turkey using some coagulants and Turkish clays as coagulant aids, Water Research, 32 (11) 3495-1499, 1998.

[8] Duan J., Gregory J., Coagulation by hydrolyzing metal salts. Advanced Colloid Interface, 45, 100102, 2003.

[9] Farajnezhad H., Gharbani P., Coagulation treatment of wastewater in petroleum industry using poly aluminum chloride and ferric chloride, International Journal of Research and Review in Applied Sciences, 13 (1), 306-310, 2012.

[10] Fedala N., Lounic H., Drouiche N., Mameri N., Drouiche M., Physical parameters affecting coagulation of turbid water with Opuntiaficusindica cactus. Ecological Engineering, 77, 33-36, 2015.

[11] Gunaratna K R., Garcia B., Anderson S., Dalhammar G., Screening and evaluation of natural coagulants for water treatment, Water Science Technology: Water Supply, 7 (5/6), 19 25, 2007.

[12] HACH Company, Water Analysis Handbook. Hach Company, Colorado.

[13] Hu C.Y., Lo S.L., Chang C.L., Chen F.L., Wu Y.D., Ma J.L. (2013), Treatment of highly turbid water using chitosan and aluminum salts, Separation And Purification Technology, 104, 322-326, 1997.

[14] Hayrapetyan S.S., Mangasaryan L.G., Tovmasyan M.R., Khachatryan H.G., Precipitation of aluminum hydroxide from sodium aluminate, by treatment with formalin, and preparation of aluminum oxide, Acta Chromatographica, 16, 192-203, 2006.

[15] LancinéG. D., Bamory K., Raymond L., JeanLuc S., Christelle B., Jean B., Coagulationflocculation treatment of tropical surface water with alum for dissolved organic matter (DOM) removal: influence of alum Dose and $\mathrm{pH}$ adjustment, Journal of International Environmental Application \& Science, 3 (4), 247-257, 2008.

[16] Liang Z., Wang Y., Zhou Y., Liu H., Wu Z., Variables affecting melanoidins removal from molasses wastewater by coagulation/flocculation, Separation and Purification Technology, 68, 382-389, 2009.

[17] Libecki B., Dziejowski J., Optimization of humic acids coagulation with aluminum and iron(III) Salts, Polish Journal of Environmental Studies, 17 (3), 397-403, 2008.

[18] Ndovu L.J., Afolayan A.J, Nutritional analysis of the South African wild vegetable Corchorus Olitorius L, Asian Journal of Plant Sciences, 7 (6), 615-618, 2008.

[19] Oyedeji K.O., Bolarinwa A.F., Effect of Corchorus Olitorius extract on haematological and plasma biochemical parameters in Male Albino rats, IOSR Journal of Dental and Medical Sciences, 3 (5), 68-71, 2013.

[20] Özacar M., Şengil I.A.,The use of tannins from Turkish acorns (valonia) in water treatment as a coagulant and coagulant aid, Turkish Journal Of Engineering and Environmental Sciences, 26, 255-263, 2002.

[21] Patel H., Vashi R.T., Removal of congo red dye from its aqueous solution using natural coagulants, Journal of Saudi Chemical Society, 16, 131-136, 2012.

[22] Poumaye N., Mabingui J., Lutgen P., Bigan M., Contribution to the clarification of surface water from the Moringa oleifera: case m'poko river to Bangui, central African republic, Chemical Engineering Research and Design, 90, 2346-2352, 2012.

[23] Raghuwanshi P.K., Mandloi M., Sharma J., Malviya H.S., Chaudhari S., Improving filtrate quality using agrobased materials as coagulant aid, Water Quality Research Journal of Canada, 37 (4), 745-756, 2002.

[24] Tassinari B., Doherty S., MarisonI W., Submicron capsules extracted from rapeseed as 
novel flocculant agents for the treatment of turbid water, Water Research, 47, 4957-4965, 2013.

[25] Ugonabo V.I., Menkiti M.C., Onukwuli O.D., Coagulation kinetics and performance evaluation of corchorusolitorus seed in pharmaceutical effluent, International Journal of Multidisciplinary Science and Engineering, 3 (7), 20-32, 2012.

[26] Wilen B.M., Jin B., Lant, Impacts of structural characteristics on activated sludge floc stability, Water Research, 37, 3632-3645, 2003.

[27] Yan M., Wang D., Yu J., Ni J., Edwards M., Qu J., Enhanced coagulation with polyaluminum chlorides: Role of $\mathrm{pH} / \mathrm{alkalinity}$ and speciation, Chemosphere, 71, 1665-1673, 2008.

[28] Yang Z., Gao B., Wang Y., Zhang X., YueQ.,Relationship between residual Al species, floc operational parameters and coagulation performance during reservoir water treatment by PAC-PDMDAAC, Separation and Purification Technology, 102, 147-156, 2013.
[29] Yang Z.L., Gao B.Y., Yue Q.Y., Wang Y., Effect of $\mathrm{pH}$ on the coagulation performance of $\mathrm{Al}$ based coagulants and residual aluminum speciation during the treatment of humic acidkaolin synthetic water, Journal of Hazardous Material, 178 (1-3), 596-603, 2010.

[30] Zemmouri H., Drouiche M., Sayeh A., Lounici H., Mameri N., Coagulation flocculation test of keddara's water dam using chitosan and sulfate aluminum, Procedia Engineering, 33, 254-260, 2012.

[31] Zhao S., Gao B., Wang Y., Yang Z., Influence of a new coagulant aid-enteromorpha extract on coagulation performance and flocs characteristics of aluminum sulfate coagulant in kaolin-humic acid solution treatment, Colloids and Surfaces: A Physicochemical Engineering Aspects, 417, 161169, 2013. 


\section{مادة بيو مجمعة جديدة مساعدة لمعالجة المياه ذات العكارة العالية وتحتوي على الأحماض الابالية}

$$
\begin{aligned}
& \text { حسام الطاهر 1‘2، طارق خليل3، رضا أبو بيه4 } \\
& 1 \text { قسم تقنية الهندسة الكيميائية، كلية ينبع الصناعية، السعودية }
\end{aligned}
$$

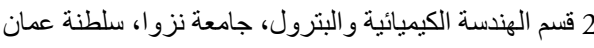

$$
\begin{aligned}
& 3 \text { قسم الهندسة الكيميائية، كلية الهندسة، جامعة المنيا، مصر جلئر }
\end{aligned}
$$

الملخص:

يتم إنتاج المياه الصالحة للثرب من معظم مصادر المياه عادة عن طريق التخثر وذلك لإزالة العكارة. و تستخدم الثبة بشكل واسع لهذا الغرض. ومع ذلك، هناك قلق حول المخاطر المرتبطة بالثبة مثل مرض الزهايمر. ونتيجة لذلك، كان هناك اهتمام كبير في تطوير مواد تخثر طبيعية من أجل تقليل جرعة الثبة. تهدف هذه الدراسة إلى تقييم استخدام سيقان أحد انواع الخضروات (الملوخية) و التي تعتبر كخلف زراعي لهذا الغرض. و هذا النوع من الخضار يزرع بوفرة في أفريقيا والثرق الأوسط. و الميزة الهامة لهذا المخلف الزراعي انه لا يحتاج إلى أي معالجة كيميائية. أجريت الاختبارات لتقييم الجرعة المتلى والثروط المطلوبة لتحقيق الإز الة المتلى لكل من التعكر والاحماض الدبالية من المياه. وبناء على نتائج الاختبار فهذه المادة تساعد على تخثر الماء بكفاءة كبيرة. اثتتت النتائج المعلية قدرة هذه المادة على تقليل جرعة الثبة من 600 ملغ/لتز إلى 300 ملغم/لتز و تقليل العكارة المتنقية من 5.63 الى 2.3 وحدة عكارة (NTU). خفضت هذه المادة تركيز الكربون العضوي الكلي (TOC) الى مستوى الصفر، كما انها ساعدت على ارتفاع سرعة التخثر. 